\title{
VESTÍGIOS DE AULA: poética didática e transcriação curricular
}

Maria Idalina Krause de Campos

Resumo

Este artigo defende a transcriação curricular como um movimento de pensamento gerativo ao afirmar uma poética didática, que envolve Corpo-Espírito-Mundo. Mostra que a Aula é uma atividade estética, política e filosófica, cujos vestígios de leitura e escrita (escrileitura) promovem a reinvenção empírica de arquivos, que passam a ser traduzidos, atualizados e transcriados, tornando-se uma potência de criação no campo da educação. Conclui que os procedimentos tradutórios postos a funcionar no espaço-aula através do Método Espiritográfico - , possibilitam a efetivação de um sonho didático e de uma poesia curricular, para criar uma escrita aventureira que transforma o conhecimento em invenção, tecendo novas costuras poéticas que ornam de diferenças as práticas docentes.

Palavras-chave: aula; arquivo; currículo; didática; docência

\section{VESTIGES OF A CLASS: didactic poetics and curriculum transcreation}

\begin{abstract}
This paper defends curriculum transcreation as a movement of generating thought by affirming a didactic poetics, which involves Body-Spirit-World. It shows that the Class is esthetical, politic and philosophical activity whose vestiges of reading and writing (reading-writing) promote the empirical reinvention of archives, which start being translated, updated and transcreated, thus becoming a creation potency in the field of education. It concludes that translating procedures put to work in the class-space - by means of the Spiritographic Method - enable the effectuation of a didactic dream and curriculum poetry in order to create an adventurous writing that turns knowledge into invention, sewing new poetic seams, which adorn teaching practices with differences.
\end{abstract}

Keywords: class; archive; curriculum; didactics; teacher practice

\section{VESTIGIOS DEL AULA: poética didáctica y transcreación curricular}

\section{Resumen}

Este artículo defiende la transcreación curricular como un movimiento de pensamiento generativo al afirmar una poética didáctica, que envuelve Cuerpo-Espíritu-Mundo. Muestra que el Aula es una actividad estética, política y filosófica, cuyos vestigios de lectura y escrita (escrilectura) promueven la reinvención empírica de archivos, que pasan a ser traducidos, actualizados y transcreados, volviéndose una potencia de creación en el campo de la educación. Se concluye que los procedimientos de traducción puestos a funcionar en el espacio-aula - por medio del Método Espírito-gráfico - posibilitan la realización de un sueño didáctico y de una poesía curricular para crear una escrita aventurera que transforma el conocimiento en invención, tejiendo nuevas costuras poéticas, que adornan de diferencias las practicas docentes.

Palabras clave: aula; archivo; currículo; didáctica; docencia 
Vivemos em um tempo de inquietudes que assolam nossos dias. A pandemia varre o planeta em um carnaval de mortes anunciadas, causadas pelo coronavírus (COVID-19). Para que não se morra pelo surto da doença, foram detalhados hábitos de higiene preventivos recomendados pela Organização Mundial da Saúde (OMS), entre eles, o uso da máscara como fundamental para evitar a circulação do vírus. Nosso trânsito entre pessoas ficou bem mais esparso, mas fez com que desenvolvêssemos um olhar de lince para identificar pessoas no olho no olho.

Obrigamo-nos a ficar em isolamento, assustados a princípio, tentando criar soluções para nos reaproximarmos daqueles por quem temos afeto e amizade intelectual. As lives surgiram com força, armando nossa sensibilidade para uma nova cosmologia do olhar e de viver em transmissões ao vivo pelas redes sociais. Uma maneira para manter viva a chama de quem vive em pesquisa e continuar produzindo, mesmo diante do infortúnio geral.

Paul Valéry, em seus escritos, fala da sensibilidade como uma mola diabólica de que se utiliza o espírito no trânsito da existência. Escrever este artigo em meio à pandemia é verificar que a mola se estica tristemente, quando nos damos conta de que expressamos bem mais: meus sentimentos! Do que: vivas! Viver ou sobreviver no caos pandêmico tornou-se uma luta de forças, e podemos dizer, como o Fausto, de Valéry (2010, p. 56), que "[...] o espírito sopra onde pode, o que pode".

Tais circunstâncias fizeram-me pensar também nas gravuras de Albert Flocon (19091994) e em sua metáfora a água do olhar, em que apenas uma parte do rosto já se configura como um mundo, um cosmos. E tal mundo oferece-nos ambivalências oriundas da imaginação, pois passamos a viver entre pequenas e grandes dimensões cosmológicas. Segundo Gaston Bachelard (1985, p. 72), para Flocon, "[...] a pupila é um poço e sobre os círculos da íris navegam barcos a vela. Depois vem a zona de limpidez, a grande bacia das lágrimas. Mas tudo isso é tão vasto que os pesares são leves".

Este artigo buscará ser leve e, com um olhar de resistência, fará sobrevoos no território da Aula, na captura de seus vestígios tradutórios. A leveza à qual nos referimos "[...] está associada à precisão e à determinação, nunca ao que é vago ou aleatório", como diz Ítalo Calvino (1990, p. 28) que, para sustentar tal afirmação, recorre a Valéry (apud CALVINO, 1990, p. 28), pois "[...] é preciso ser leve como um pássaro e não como a pluma", ou seja, somos nós mesmos que comandamos nossas ações, traçamos nosso plano de voo e flanamos mediante o movimento preciso que imprimem nossas asas.

E a tarefa não é simples, mas uma aventura de descoberta; mesmo que o mundo esteja pesado e triste, possui seus encantos, seus rastros, seus horizontes, onde é possível perceber certa alegria de olhares espantados dos que insistem em pesquisar em educação. E essa alegria solidária, baseada em encontros de uma amizade ética (philía), pensa e sonha para fazer vicejar no campo da educação uma poética didática e uma transcriação curricular necessária, que dinamiza e movimenta a imaginação, visto "[...] que nada é fixo para aquele que alternadamente pensa e sonha...” (BACHELARD, 1985, p. 95).

Trata-se de dar a ver uma articulação imagética entre didática e currículo, em que pensar e sonhar se afirmam como uma poética possível na educação contemporânea. Poética que se cria em um processo de composição de escrita e contempla um viés estético, político e filosófico que envolve Corpo-Espírito-Mundo (CEM). Pois, como afirma Valéry (2011, p. 215), “[...] tudo passa entre o que denominamos o Mundo Externo, o que denominamos Nosso Corpo, o que denominamos Nosso Espírito". Abre-se, assim, um campo educativo virtual, ficcional e tradutório em que o espírito se encontra consigo mesmo e, também, com suas circunstâncias de mundo, em um determinado tempo e espaço, passando a funcionar em atravessamentos entre a 
realidade e o sonho. Isso possibilita que nossa sensibilidade crie itinerários singulares e, assim, levante questões que digam de nossas inquietações mais prementes, visto que "[...] é o que contenho de desconhecido a mim mesmo que me faz ser eu mesmo" (VALÉRY, 1997, p. 59). E o desconhecido é sempre uma abertura - um arquivo -, uma possibilidade nova de ler e interpretar a realidade.

Nesse itinerário rumo ao desconhecido, o Método Espiritográfico (CAMPOS, 2018) serve como um mecanismo de composição de escrita, isto é, um gerador para uma atividade estética de ações escrileitoras e de viés valéryano. Efetiva-se como um jogo poético, como um disparador tradutório de arquivos no campo da educação, por meio do manejo de matérias, tanto da arte quanto da ciência, da filosofia e da literatura, possibilitando a germinação de uma escritaartista que desvia da trivialidade da mera transmissão de conhecimentos - até porque a ela interessa a escrileitura como ação tradutória transcriadora, vista mais como meio de produção de escrita do que como um fim ou uma meta.

Sendo assim, os procedimentos tradutórios de leitura e de escrita postos a funcionar no espaço-aula possibilitam a efetivação de um sonho didático e de uma poesia curricular, capazes de gerar uma escrita aventureira que se reinventa no exercício cotidiano do magistério, o que se configura como uma fonte para a criação de novas práticas docentes. Tais exercícios tradutórios são também políticos e prezam a ética nas relações no âmbito pessoal, coletivo, institucional, e, à medida que são compartilhados, propiciam o fortalecimento cultural ao trazerem novas costuras e ressignificados poéticos que ornam de diferenças o tecido social.

Dividiremos este artigo em quatro segmentos intercambiáveis: 1) Andejar em pesquisa sinaliza de onde estou falando; 2) Vestígios de Aula - expõe uma perspectiva dos estudos e movimentos de pesquisa; 3) Aula: práticas de microcomposições espiritográficas que afirmam o processo de escrileituras de viés valéryano e que faz uso do conhecimento com invenção; e 4) Considerações finais.

\section{Andejar em pesquisa}

Uma vida de pesquisa é um andejar observando nossos próprios fluxos de pensamento. Nessa errância existencial, perseguimos algumas ideias que consideramos fecundas e, por necessidade, as investigamos com rigor, visando a adentrar um determinado domínio do que nos é caro. Trata-se de planos de pensamento que penetramos, voltando nossa atenção para os vãos e arestas de onde possam emergir: imagens, figuras, acontecimentos, personagens, vozes, que descobrimos por meio da escrita e da leitura. Nesses encontros férteis, acusam-se novos tipos de visões, afirmando descobertas que potencializam nossa vontade de pesquisar.

Assim, o professor pode assumir o papel de demiurgo, não como artesão divino de concepção platônica, um modelador ideal da matéria, mas, ao contrário, como um operário que atua com ações manuais, como um empirista do in/forme. Somos demiurgos da variação e, entre o sono e a vigília, alquimicamente, trazemos à baila as imagens dos sonhos noturnos para fantasiarmos conceitos na luz do dia da docência.

Nesse trânsito entre realidade e sonho, rabiscamos nossas invenções de escrita poéticas, ou seja, fazemos um movimento de tradução, em que traduzir é também se traduzir. O professor, então, torna-se um crítico de si mesmo, e sua criticidade associa-se intimamente ao seu fazer docente. Fazemos operar um movimento oscilatório, impreciso, errante, de escrita na busca de nitidez, sagacidade e lucidez de pensamentos. Isso para compor uma escrita que se retroalimenta, pois, percebemos que, nos arquivos que manipulamos, há sempre domínios ainda inexplorados, trajetórias a serem traçadas, relações novas a serem estabelecidas, procedimentos a serem criados 
e desenvolvidos, que amenizam as dores reais que por vezes sentimos ao sonharmos a vida, a pesquisa, a docência.

Valéry (2011, p. 95) afirma que “[...] o sonho fica aquém da vontade”. Nele agimos sem querer; queremos sem poder; sabemos sem nunca ter visto, antes de termos visto; vemos sem prever. Porém, tudo que ocorre nos sonhos serve como dispositivos para pensar e criar. E pensar é uma maneira de enfrentar a realidade, pois "[...] o real é aquilo do que não se pode acordar, aquilo de que nenhum movimento me tira, mas que todo o movimento reforça, reproduz regenera" (VALÉRY, 2011, p. 95). Os sonhos são inacabados e, quando trazidos à consciência, configuram-se como um manancial de ideias oníricas, o que serve como disparador para uma docência poética, bem como para fantasiar aulas, pois, se penso, sonho e, se sonho, penso.

E nesse fazer, procuramos algo da ordem do ineditismo poético, da fantasmagoria, do imaginativo, em que o pensamento se estira como um sonho sonhado em plena luz, ou mesmo na sombra de um dia. Na caça de um instante que faz vibrar um si mesmo de um espírito que se espanta e, com esse pasmo, se vivifica e faz da matéria efervescência transcriadora: substância volátil de escrita traduzida em acontecimentos raros expressos por meio da linguagem.

Tudo quanto foi dito até aqui demonstra que, em nossa trajetória de vida, do nascimento até a morte, lidamos com os meandros da linguagem e, por via de consequência, fazemos movimentos de pensamento que são tradutórios. De acordo com Otávio Paz (2009, p. 19), “[...] aprender a falar é aprender a traduzir". Desde a infância, nossas traduções diante do mundo funcionam como um dispositivo fônico, ou seja, um meio de expressão ativo para emitir sons e vozes para que algo se diga.

Começamos, então, a fazer uso da linguagem comum - linguagem simples, com que se estabelece uma espécie de dança. Dança do uso dos signos que possibilitam a comunicação. Por uso, entende-se: possibilidade de escolha dos signos, combinação, signo como instrumento, como produto de escolhas. Nosso espírito busca uma maior consciência de si, dá atenção a seu intelecto labiríntico e investiga-o em sua real fragilidade. Tal investigação ocorre porque não há em nosso intelecto uma homogeneização de pensamentos, mas variedade de ideias em fluxo de forças constantes. Esse fluxo deixa ver que a racionalidade é permeada de luzes e de obscuridades, fruto de instabilidades, de impermanências e das oscilações do próprio pensar não ordenado.

Diante dessas obscuridades, procuramos pensar com maior lucidez, ou seja, passar da desordem ao ordenamento mais rigoroso das ideias. Montamos um laboratório próprio onde nosso espírito ocupa três lugares funcionais intercambiáveis, que chamo de EEE (CAMPOS, 2018): a) o de Estudante (espírito que desde a infância percorre um curso tradutório de escrita e leitura); b) o de Escritor (espírito autor, tradutor e transcriador de textos); e c) o de Educador (espírito em exercício de tradução na prática da pesquisa-docência).

Nesse atravessamento entre lugares, é possível construir uma poética que dispara sentidos, pois é ativada como força propagadora para criações autoeducativas que se afirmam entre o currículo e suas unidades analíticas: Espaços, Imagens e Signos (EIS); e a didática com suas unidades analíticas: Autor, Infância, Currículo, Educador (AICE).

Essa poética busca promover encontros para estudos e práticas educativas com ênfase na escrileitura - mediante as aventuras do intelecto - que propiciam ao espírito construir a sua própria realidade no campo ambiental da linguagem. Por este viés, os conceitos de percepção e de criação tornam-se dois meios possíveis para movimentos experimentais do pensar, visando a falar e escrever sobre AICE (Didática). Trata-se de uma empiria que, por meio de um mecanismo - operatório e conceitual -, dá impulso ao pensar exploratório, recusando a intervenção do juízo e desconstruindo os saberes constituídos, para criar uma nova escrita, por vir. 
Assim, o currículo (EIS), é posto em movimento por meio de um nomadismo intelectual, experimentado na própria superfície da educação. Para que esse processo ocorra, valemo-nos dos procedimentos múltiplos de escrita de Paul Valéry para um fazer tradutório em educação. Tomamos dos escritos de Valéry lumes procedimentais potentes, como faíscas lançadas sobre a escuridão labiríntica do ainda não descoberto pelo pensamento, para com eles viver e criar, de modo a "[...] maquinar a educação, com prazer aventureiro e espírito aventuroso" (CORAZZA, 2014, p. 5).

Dessa maneira, AICE (Didática) e EIS (Currículo) tomam para si uma poética de pesquisa que se quer empírica, em um processo de releitura e de reescrita do vivível no campo educativo, e que produz um currículo e uma didática da diferença, ao passo que cria novas epistemologias educacionais, possibilitando pensar uma poética didática e uma transcriação curricular em que as ações tradutórias deixam vestígios e sinais espargidos no espaço-aula. Vestígios de pensamentos comuns e de pensamentos raros, pois: “[...] mesmo o mais sábio executa o movimento demasiado humano de tropeçar naquilo que não entende" (VALÉRY, 2016, p. 106).

No âmbito de minhas pesquisas, foi possível criar o Método Espiritográfico, explorando a multiplicidade dos procedimentos de escrita de Paul Valéry, para ser usado na educação. Trata-se de lidar com o informe, de utilizar o conhecimento como invenção, visto que o método funciona no espaço-aula como um disparador poético que promove ações autoeducativas de que se vale o professor-pesquisador, pois disseminam saberes que movimentam o intelecto e impulsionam as aventuras do desejo de educar.

\section{Vestígios de aula: estudos e movimentos}

Paul Valéry (2011, p. 202), em sua primeira aula do curso de poética (1937), afirma que “[...] é a execução do poema que é o poema". Por analogia, podemos dizer que é a execução de uma aula que é a aula. A aula só existe em ato, e é nela que nos permitimos sonhar alto nossas pesquisas. Mesmo porque almejamos que ela seja feita de maneira poética e que exprima e afirme a nossa vontade potencial de educar. Colocamos nossa pesquisa na roda, e ela gira, desdobrando conceitos, para que assim novas ideias nos encontrem e nos adotem.

A aula coloca para dançar pensamentos e corpos como um dança-drama de espadas balinesas, que, por uma dinâmica corpora, coloca em movimento toda uma gestualidade performática de dedos, mãos, cabeça e olhos. A aula é um salão onde podem desfilar as bruxas e as grandes bestas, e também querubins e serafins. A Aula torna-se um espaço ocupado por espíritos dançarinos que, muitas vezes em estados de transe, performam ideias em um ritual educativo que flerta com o sensível e o inteligível.

Aula é também uma dança verbal, cuja prancha está estendida sobre o abismo da linguagem e dos signos trazidos dos arquivos que perseguimos, em uma tentativa de decifrá-los. E é isso o que nos move e nos inquieta, ao mesmo tempo em que nos possibilita revisitar autores mortos e autores vivos, verificando como seus mecanismos de pensamento foram usados para criar suas obras e como podem servir para o nosso próprio uso. Pois é com eles que lidamos na busca de novas facetas, que afirmam o ato de pensar como potência transformadora, e não reprodutora do já conhecido, que se esvazia de sentido, tornando-se frágil transmissão de saberes sem produzir mais ressonâncias.

É preciso ter o direito de sonhar aulas, para dançá-las e recriar conhecimentos, usando-os como invenção, em uma metonímia ritmada de pensamentos musicados. Levando em conta uma ofis-sofia concebida como um desafio ao intelecto que intensifica os diálogos entre pesquisas em uma dimensão coletiva e gaya, ou seja, enquanto educadores, somos guerreiros insistentes, 
poetizadores desejosos em um embate de forças semoventes impostas pelas matérias que buscamos traduzir e transcriar com gozo e com a alegria e rigor crítico de um serpensamento.

O professor, assumindo o papel de demiurgo, lida com matérias caóticas de seus arquivos, extraindo deles curiosidades vivenciais que se atualizam entre o sol e a lua. Pesquisa como um polvo que interroga as águas povoadas da docência e escolhe, salta, agita seus tentáculos na espessura das ondas vertiginosas do cotidiano do magistério, apossando-se do que lhe convém. Difere dos tolos e das esponjas, que somente aderem e não partejam novos fazeres poéticos para obras ainda não nascidas. E, se pesquisa, é porque está em busca de novos tipos de visões que capturem o ainda não visto como um desejo afirmativo e construcionista que permeia sua docência.

E a aula, com seus vestígios tradutórios e circunstanciais diários funcionarão ou não, dependendo da disposição dos convivas para bailar, mas por certo, ao adentrarmos em seu salão, “[...] não se entra jamais pela mesma porta” (VALÉRY, 1996, p. 77). Isso porque viver em aula é algo da ordem do acontecimento, em que saudamos coisas visíveis, mas fugidias, que excitam o pensamento exalando sua presença-já, em um carnaval de sensações que, como um palito de fósforo riscado, logo se apagam, mas nos deixam tragar nossos cigarros, que entre anéis de fumo nos fazem recordar uma aparição. Estamos vivendo onde o acontecimento não mais está e tornamo-nos estrangeiros sendo vividos por ele, que com seus rastros e marcas nos consome.

Aprendi com Paul Valéry (1932, p. 9) que "[...] o mais profundo é a pele", a captadora de estímulos sensórios traduzidos pela linguagem, quando não há uma ideia fixa (l'idée fixe), mas pensamentos que buscam acontecer - movimentando Corpo-Espírito-Mundo -, tendo a pele, o tecido epitelial, como uma superfície preciosa e frágil. Ela se estende e distende, se esgarça para que nossa sensibilidade capture acontecimentos traduzidos via palavra, cuja força de expressão se afirma em uma escrita encarnada potencialmente.

Olho, pele e mãos funcionando como um meio de câmbio tradutório carnal que se expressa via linguagem errante. Câmbio que realiza uma inversão, fazendo uma crítica à profundidade essencialista apregoada pelo ideal platônico, para cantarolar uma nova ode e enaltecer a superfície, concebida como um plano de pensamento potencial para o vivo acontecimento.

Recorrendo a Haroldo de Campos (2008, p. 183), a ação tradutória configura-se também como uma "[...] operação radical, cuja virtude transfusora" funciona no instante em que passa a vivificar as matérias contidas na fonte original (obra/arquivo), o que, concomitantemente, nutre o tradutor em um movimento de recirculação textual novo. Tal possibilidade ocorre porque todo e qualquer conhecimento que nos propomos passa necessariamente pela linguagem, e abre espaço para a transcriação.

A cada nova leitura ou mesmo releitura que fazemos de determinado arquivo, gera-se um novo texto - sonhado - no texto lido. Em tal acontecimento, decretamos a morte do autor para assim celebrar a vida nova do texto, concebida pelo leitor, que também é um escritor. De acordo com Roland Barthes (2012, p. 62), o texto é um "[...] espaço de dimensões múltiplas, onde se casam e se contestam escrituras variadas, das quais nenhuma é original".

Isso faz com que a poética didática à qual nos referimos entoe um canto paralelo ao texto original, o que se desenvolve por meio de um movimento plagiotrópico em uma agoridade. $\mathrm{Ou}$ seja, a cada vez que colocamos um texto na esteira tradutória, fazemos emergir uma poética didática revigorada, efetivamente marcada pelo trânsito entre o texto original e sua transcriação.

Trata-se de uma ação sanguínea, pois nos nutrimos do sangue alheio ao traduzir e, de certa maneira, contaminamos o arquivo original. Bebemos do sangue que deu e dá vida, em uma prática de "[...] transluciferação mefistofáustica" (CAMPOS, 2013, p. 215), que não apenas 
vivifica o original. Como um ato visceral, faz o sangue circular, pulsando veias e interferindo de maneira afirmativa na prática docente, que tem fome de vida e necessita de refeições sacrificatórias constantes para permanecer atuante.

O educador-tradutor, diz Haroldo de Campos, "[...] vampiriza, o que corresponderia à ideia de mutabilidade do original pela atuação crítica de sua tradução" (CAMPOS, 2013, p. 217). Conquista-se um espaço vital para traduzir, abrindo-se uma porta para uma transcriação manifesta, expondo sua alteridade singular, dimensionada como condição de vida na qual a tradução lhe dá sustentabilidade e também a constitui.

Dessa maneira, as traduções das matérias originais, advindas da arte, da ciência e da filosofia (DELEUZE, GUATTARI, 1992), expressam-se, inicialmente, no currículo (EIS) e, mais adiante, na cena dramática da aula, em um processo de criação e recriação sem fim. Isso implica que o fazer didático (AICE) e o curricular (EIS) estejam interligados em um movimento tradutório duplo, cujos produtos são sempre imprevisíveis e provisórios, sujeitos a permanentes revisões que, desse modo, tendem a fazer oscilar as certezas e as verdades herdadas, seja no campo da arte, da ciência ou da filosofia.

Por esse viés, tanto a didática quanto o currículo da tradução opõem-se ao realismo e ao idealismo. São sensíveis às imagens de pensamento e questões culturais, além de circularem em um misto de empirismo transcendental, quando partem de uma matéria para alcançar o campo da virtualidade, que privilegia a multiplicidade (DELEUZE, 1988).

Nessas condições, a educação é vista como um espaço de ficção onde a aula é planejada para que, de algum modo, funcione transcriadoramente, como um laboratório individual e coletivo que reexamina conhecimentos e promove uma educação do espírito, uma vez que sobre eles passa a levantar novos problemas. Esse levantamento de questões dá-se por uma vontade de potência de educar - e, também, de aprender - como um exercício de atividade estética, política e filosófica que traz em seu bojo as categorias tanto da poesia quanto do sonho.

\section{Aula: prática de microcomposições espiritográficas}

A aula, como se vê, é um território onde manipulamos matérias de arquivos múltiplos e rastreamos, como artífices, planos de pensamento diversos. Isso ocorre porque investimos em leituras e escritas (escrileituras) constantes e passamos a atualizar matérias mediante estudo e pesquisas que esboçam um novo olhar sobre os dados neles contido, visto que "[...] a retina faz contemporânea todas as coisas" (VALÉRY, 2016, p. 45).

Por intermédio dessas atualizações, criamos condições para uma escrita-artista que propicia lidar com o ainda não visto, exercitando as impressões visuais que se demoram nas sensações e concebendo uma visão singular e axiológica para o ainda não significado, não interpretado ou a que ainda não se atribuiu valoração por não ter sido descoberto. Estes movimentos de pensamento são possíveis, pois, para a Filosofia da Diferença, não se concebe a docência sem a ação empírica da pesquisa. Elas necessariamente andam juntas como potência de transformação renovável do próprio devir da vida e do fazer docente.

Daí podermos imaginar a aula como uma ilha onde pensadores nômades promovem uma dracomédia do intelecto (CAMPOS, 2018). Entre dramas e comédias, eles vivem como um Robson Crusoé, ou como Sexta-feira, extraviados em uma ilha de carne e espírito, rodeados por todos os lados de arquivos que chegam à praia da docência, para que com eles fabriquem os seus instrumentos e sua arte para sobreviver.

Sim, planejar aulas e efetivá-las é uma arte. Como toda arte, necessita antes ser rabiscada, estudada, ensaiada, pensada. Isso porque "[...] pensar é experimentar, mas a experimentação é 
sempre o que se está fazendo - o novo, o Notável, o interessante, que substituem a aparência de verdade e que são mais exigentes que ela" (DELEUZE, GUATTARI, p. 139). Dessa maneira, embarcamos em uma ofis-sofia ilimitada e entregamo-nos a seu planejamento sem prever um fim, em um transe interrogativo que faz parte de nosso ofício, e perguntamo-nos: a) Mas o que é a aula, afinal?; b) Existem tipos de aula?; c) Quais vestígios de ideias nela se articulam e se disseminam?

Para tentar elucidar tais questões, colocamos a funcionar o Método Espiritográfico como um disparador poético, para que com ele comecemos a lançar novas luzes sobre a superfície da aula, na busca de seus vestígios. Método que está inserido nas pesquisas pós-críticas no campo da educação. Apostando nas operações inventivas do pensamento que colocam textos em recirculação em uma esteira tradutória. Textos que se atualizam por meio de uma ação do espírito que lê e escreve, que quer dizer-se, autoeducar-se, explorando as potências da linguagem dentro de um processo de culto ao intelecto.

Trata-se de voltarmos nosso caleidoscópio para o eixo da história da humanidade e de elencarmos alguns personagens para com eles produzir um texto sobre tipos de aula possíveis. Desses personagens, destacamos detalhes de uma trajetória de vida ou de pensamento que nos chamem atenção, visto que nos interrogam ou nos afetam de determinada maneira por terem deixado seus rastros e, também, seus enigmas.

Assim, já temos matéria palpável para compor microcomposições de escrita que sejam artistadas espiritograficamente, ou seja, por meio de escritas e leituras, vamos ao mundo desses espíritos criadores, vasculhamos arquivos, os traduzimos e os transcriamos, fazendo com que esses personagens emitam vozes. O discurso a ser elaborado é livre, porém, há um regramento quanto à extensão de cada texto com relação ao número de linhas exigidos na composição, o que não pode de maneira alguma ser ignorado, pois é parte do desafio empírico de escrita.

Aula: dos sete reinos ao jardim

[6 linhas]

Confúcio (551 a.C.), pensador oriental, demitiu-se de um cargo oficial do Estado, preferindo viajar durante 14 anos pelos sete reinos e conversar para atrair discípulos. Depois dessas andanças, retornou à sua terra natal e passou a ensinar seus estudantes enquanto reunia e ordenava livros clássicos, até morrer, contando 73 anos. Já Epicuro (341 a.C.), filósofo ocidental, preferia os jardins e fundou sua própria escola filosófica, chamada O Jardim, onde residiu cercado de alguns amigos, em plena ataraxia, na cidade de Atenas.

Aula: trevas e magia

[11 linhas]

Hipátia, a filósofa pagã, era professora na Academia de Alexandria e desenvolveu seus estudos sobre matemática, medicina e astronomia na biblioteca; por sua rebeldia de pensar, foi esquartejada viva e depois queimada na ágora. Platão, por sua vez, criou a academia para transmitir dialogicamente seus saberes. Aristóteles fundou o liceu por onde desfilavam peripateticamente seus discípulos em aulas itinerantes.

No início da idade das trevas, o mestre do ocidente Boécio pretendia traduzir as obras de Platão e Aristóteles, mas foi preso por traição e, por utilizar-se da magia, foi executado, não atingindo seu intento. Ainda no cárcere, escreveu De consolatione philosophia, após ter visto uma aparição da própria filosofia em sua cela. A dama espectral prometia-lhe conduzi-lo à verdadeira felicidade, pois, segundo ela, a angústia do sábio é uma oportunidade para fortalecer sua sabedoria.

Aula: saltos e destinos

[9 linhas]

Dando um salto de pensamento para a era moderna e adentrando no contemporâneo, Nietzsche abandona suas aulas e o posto de professor na Universidade de Basileia. Dizem à boca 
pequena que sua voz era inaudível, o que afastava os alunos. Optou pela vida errante, distante dos gabinetes empoeirados, e criou o hábito de pensar ao ar livre para adquirir pensamentos lúcidos, com os quais edificou suas obras.

Schopenhauer foi convidado a lecionar na Universidade de Berlim. Em suas aulas e conferências, atacava criticamente o pensamento de Hegel e logo se sentiu isolado; diante de salas de aulas com cadeiras vazias, pediu demissão. Fugindo da epidemia de cólera que varria a Europa na época, acabará seus dias em Frankfurt, onde exercita sua arte de escrever.

Aula-de fazer

[57 linhas]

Paul Valéry ministra tardiamente sua primeira aula de poética no Collège de France em 10 de dezembro de 1937. Em sua fala inicial, disse: “[...] para mim é uma sensação muito estranha e muito emocionante subir nesta tribuna e começar uma carreira totalmente nova em uma idade em que tudo nos aconselha a abandonar a ação e a renunciar ao trabalho" (VALÉRY, 2011, p. 195). E passou a falar sobre a sua concepção singular de poética.

Valéry, em sua aula, tratou do conceito de poética de uma maneira nitidamente retórica, desenvolvendo uma noção bem simples de fazer, a qual chamou de obras do espírito e que podemos chamar de arquivos do espírito. Tais obras "[...] são aquelas que o espírito quer fazer para seu próprio uso, empregando para esse fim todos os meios físicos que possam lhe servir" (VALÉRY, 2011, p. 197). De qual ato físico se utilizou o autor para fazer sua obra? O que essa obra me levou a pensar/meditar? Sobre o que ela me levou a interrogar? Quais problemas foram suscitados em mim ao lê-la?

Tal poética efetivar-se-ia, segundo ele, como ato de pensamento se ela nos causasse curiosidade, um interesse vivo, o que nos leva a perguntar: qual a ação que faz com que eu a siga? Do que a coisa/obra é feita? O que custou sua produção? Qual o valor de uma obra/arquivo?

$\mathrm{Na}$ fala de Valéry, há todo um uso de palavras da economia, como: Produção/Produtor e Consumidor, que é o leitor, ou o ouvinte, ou o espectador. E o que agrega valor a uma obra/arquivo como a Ilíada, de Homero, é seu "ouro". O ouro da raridade e da inimitabilidade. A Ilíada não foi imitada por ninguém; é um arquivo que contém uma obra rara, o que privilegia seu valor elevado. Esta economia da obra alia-se a uma política da obra, ambas se constituem por uma ideia de trabalho, ideias de criação, acúmulos que riquezas, oferta e demanda.

O produtor (autor) e o consumidor (leitor) - isso se tratando de uma obra escrita - são dois sistemas separados que formam uma relação de três termos: o produtor, com sua ação de fazer a obra; A obra feita; e o consumidor, que tem a reação diante da obra feita. A ação de fazer do produtor levou um tempo para ser feita, uma vida, às vezes, como Goethe ao escrever seu Fausto. O consumidor, ao ter contato com a obra, sofre seus efeitos, o que é declarado por vezes em alguns instantes, e não conferindo a ele seu real valor.

Um instrumento musical construído pelo compositor para ordenar uma peça e formar seus versos é outro exemplo trazido. O que esse fazer implica - poderíamos perguntar. Ou uma obra de arte que, em um primeiro olhar, nos faz sentir o choque de suas forças sobre nós. Ou os filósofos, que muitas vezes retêm seus pensamentos por atos de escolhas, transações mentais que os levaram a finalizar sua obra, a fim de "[...] comover, surpreender, deslumbrar ou desconcertar o espírito do Outro, submetido à excitação dessa enorme carga de trabalho intelectual" (VALÉRY, 2011, p. 200).

São ações desmedidas (sem medidas), exorbitantes, colocadas em curso para compor uma obra. Toda uma força sobre-humana, mas muitas vezes ao lermos a obra tal efeito não se produz, pois ele pode ter um efeito negativo ou mesmo nulo, não há garantias! Ou a obra pode causar um grande efeito. Somos vencidos pelas forças que dela emanam e nos atravessam: as forças da 
perfeição, composta pelo grande número de lances felizes que deixa ver e pelas surpresas que tudo isso nos causa.

Embora constatando tudo isso, não se pode imaginar todo o trabalho interno do espírito para a produção de uma obra, seu caos mental e mesmo a química alquímica do espírito produtor. Poderíamos perguntar “o que a obra produz em nós?”, e não saberíamos por instantaneidade dizer, pois no espírito que a produziu há toda uma singularidade própria, uma arquitetura de pensar usada como meio de produção, a qual por curiosidade tentamos descobrir. E nesse processo de descoberta, o consumidor torna-se também produtor, uma vez que é ele quem dará valoração à obra. Ou seja, torna-se um produtor e intérprete transcriador de um ser imaginário que fez algo que ele admira.

A aula valéryana, ao ser feita e exposta ao público, configura-se como uma poética espiritográfica viva que coloca os arquivos de obras raras em perspectiva, em uma ação em que o “[...] fazer: é apenas refazer através do pensamento" (VALÉRY, 2011, p. 104). E finaliza sua retórica com a mesma elegância com que começou; faz uma série de agradecimentos reiterados pelo convite recebido. Valéry (2011, p. 208), então, emite sua consideração final sobre a temática exposta: "[...] esforço-me para nunca esquecer que cada um é a medida das coisas". Enquanto era aplaudido, acendeu seu cigarro.

Aula-diálogo-comprimido

[5 linhas]

Então, meu caro Sr. Freire, o que defendes é uma pedagogia da autonomia?

Sim, Sr. Pascal, a autonomia é de natureza educativa; sem ela, não há aprendizagem.

Mas tal tarefa, Sr. Freire, é trabalhar pelo incerto; aventurar-se ao mar; caminhar sobre uma prancha!

Prancha molhada por ondas de esperança, caríssimo Blaise Pascal!

Aula-tonalidade

[21 linhas]

Roland Barthes, no Colégio de França, em 1977, em sua aula inaugural de Semiologia Literária, traz aos seus alunos um intenso texto em que fazia denúncias sobre os vigentes discursos fascistas e arrogantes, defendendo a literatura como algo libertário, ou seja, uma linguagem que difere da língua fascista e do discurso universal da doxa arrogante e logocêntrica.

Em qualquer encontro a que fosse, Barthes levava sempre consigo sua "[...] cadernetinha, jogava nela algumas notas a fim de não esquecer nada de importante" (COMPAGNON, 2019, p. 116). Chegando à casa, passava suas anotações para um grande fichário e, por vezes, convidava alguns alunos do seminário para reclassificá-los. Essas matérias, utilizaria posteriormente em seus escritos e em seus discursos de aula.

A aula de Barthes não era de uma fala magistral, mas um convite a um jogo de escritura enunciada como uma retórica clássica e impecável, contrastando com conteúdos nada convencionais, enfatizados com certo tom de ironia. Sua fala possuía uma entonação serena, porém com tom provocativo quando criticava a doxa consensual e grudenta, uma geleia pastosa oferecida pelo poder institucionalizado, feita de normas universalizantes e vis. Havia em seu discurso toda uma tonalidade que fazia do saber uma festa da escritura.

Suas aulas eram lotadas. Nelas pipocavam os gravadores, máquinas de microfitas cassetes, a alta tecnologia da época. Tecnologia incômoda, pois, após alguns minutos, seus ouvintes subiam ao palco até a mesa onde Roland estava para virarem as fitas, e ele se calava por instantes, permitindo tal operação. Contam que Foucault aproveitava o ensejo para seduzir jovens e declarava com um sorriso: "você tem uma bela máquina!" (COMPAGNON, 2019, p. 130).

Aula-magistral 
[19 linhas]

Gilles Deleuze foi professor por quase 40 anos, a princípio, no ensino médio, e depois na universidade; considerava seu estilo de aula de concepção magistral. Ele gostava de seu ofício e preparava suas aulas com esmero. Preferia o ambiente da aula ao das conferências, pois nas conferências o espaço-tempo era diminuto. Deleuze concebia a aula como um cubo, um espaço cuja temporalidade era preciosa, estendendo-se de um encontro ao outro, em uma sequência necessária em que os alunos teciam novos e mutantes pensares entre uma semana e outra.

Para que tal fato ocorresse, o assunto a ser tratado na aula deveria estar impregnado nas vísceras do professor. Para tanto, era preciso ensaiar o tema divertidamente, várias vezes, até atingir um ponto desejável de amorosidade com o assunto. Com toda essa preparação, ele almejava entrar no espaço-aula para que nela pudessem ocorrer momentos de inspiração, já que, sem ela, a aula se transforma em um nada.

A aula, para ele, era sempre uma ação de colocar matérias em movimento, em que cada aluno pegava o que lhe convinha, se fosse uma aula boa e inspirada, pois em uma aula ruim e morna ninguém pega nada, visto que a mornidão não convém a ninguém. A aula, para Deleuze, era um dispositivo móvel que buscava ensinar aos alunos meios de conviverem com a solidão. Isso para que eles pudessem manejar suas ideias, usando-as conforme suas necessidades, o que faria com que surgissem novos movimentos de pesquisa.

Gozo-docente

[8 linhas]

- Havia saído de uma aula, vagueava pelo corredor e pôde ver através das vidraças que chovia. Perdia-se em pensamentos, ouvia seus passos e deixava-se levar rumo à biblioteca. Já em sua Jangada de Medusa, o mundo de livros que a rodeava era uma sucessão de visionários apocalipses tentando suprir ignorâncias. Lia, e num instante seu olhar e seu pensamento pairaram na sombra de uma ideia, numa espécie de transe de sonho coletivo, algo raiou. Pele invadida por uma febre terçã, fado enigmático de vislumbres rápidos e fugidios, num arrebatamento perturbado, riu e escreveu: acontece por vezes, de aulas, de livros e de sonhos fazerem de nós o que querem!

Acreditamos que esses procedimentos podem servir para novos movimentos de leitura e escrita em aula, pois eles afirmam uma poética didática e uma transcriação curricular viva que deixarão na atmosfera da aula, por certo, novos vestígios tradutórios.

Trazem-se para o espaço-aula os textos literários como um arquivo valioso a ser explorado e transcriado - o que é também um ato de rebeldia contra um sistema vil que aumenta a taxação sobre os livros ${ }^{1}$, confirmando o argumento de Zola (1879, p. 24): “[...] os governos suspeitam da literatura porque é uma força que lhes escapa”.

\section{CONSIDERAÇÕES FINAIS}

Temos ciência de que a pesquisa-docência é infinda, e, mais do que resultados esperados, cabe-nos sempre investigar como ela prepara seus dispositivos funcionais em constante movimento, pois o desejo de criação da pesquisa transcende, vai além de seus resultados e objetivos. Ela passa pela escolha do conjunto de procedimentos que se deseja investir e inventar,

${ }^{1}$ Projeto de reforma do governo federal prevê cobrança de contribuição para o setor de livros. Governo calcula alíquota de $12 \%$ para novo imposto. O que trará elevação dos preços dos livros impactando o mercado editorial como um todo. Disponível em htps://g1.globo.com/pop-arte/noticia/2020/08/11/taxacao-de-livros-comoproposta-de-reforma-tributaria-pode-encarecer-obras.ghtml. Acesso em 8 nov. 2020. 
para abrir novas brechas e trazer à superfície a estética, a filosofia e a política do que acontece em termos de atualização e resistência em nossas áreas de pesquisa, investindo no desejo de transformação daquilo que está instituído e assim produzindo novos modos de diferenciação.

A maior resistência que podemos colocar em marcha, mesmo diante da pandemia que nos assola, é seguir produzindo pesquisas de qualidade que não somente façam conexões com o próprio nicho acadêmico, mas que também se permitam um fora dele, colocando-se a correr e rodar mundo e a atender aos convites das escolas, das comunidades, das periferias, que nos chamam, para assim promover encontros de vida, possibilitando novos movimentos de pensamentos que vitalizam as ações docentes e nossas próprias pesquisas.

Falar sobre o conceito aula ou mesmo falar em aula é fazer leituras de mundos como um texto interminável das mil e uma noites. É preciso ter tenacidade como uma Sherazade da educação para não renunciar ao ofício da docência. Ofício bombardeado por legislações verticais, verbas limitadas, em um desrespeito à classe, que sofre com atitudes visivelmente torpes que desprezam a labuta dos educadores. Devemos insistir nos encontros - que eles nos sirvam de meio para novas invenções, recriando culturas e discursos distanciados das metanarrativas dogmáticas e obstaculizantes, que matam o prazer com o inusitado.

Enfim, espero que este artigo, mesmo tendo sido parido com sangue na ponta dos dedos, tenha trazido um tanto de leveza. Leveza do pássaro, e não da pluma. E que sua leitura deixe ver uma visão mais ética do mundo em que vivemos, remodelando nossas visões, deixando formar-se em nós um terceiro olho, que vê além do aparente; olho da vidência-vivível que captura forças que não mutilam a vida, mas dão vida; que faça dela alegre-visão de forças que se despojam e interpenetram, vivendo e deixando viver, distantes dos cultos de automutilação e de morte que campeiam.

Então, Conatus é o que desejo. Mesmo em tempos sombrios, um esforço para que experimentemos a alegria dos encontros, e que eles aumentem nossa potência de agir e nos deixe imaginar e perceber ainda a alegria pulsante na pesquisa-docência, exorcizando a tristeza com leveza e afirmando uma amizade intelectual e ética.

\section{REFERÊNCIAS}

BACHELARD, Gaston. O direito de sonhar. São Paulo: DIFEL, 1985.

BARTHES, Roland. O rumor da língua. São Paulo: Martins Fontes, 2012.

BARTHES, Roland. Aula. São Paulo: Cultrix, 2013.

CAMPOS, Haroldo de. O arco-íris branco. Rio de Janeiro: Imago, 1997.

CAMPOS, Haroldo de. Deus e o Diabo no Fausto de Goethe. São Paulo, Perspectiva, 2008.

CAMPOS, Haroldo de. Transcriação. São Paulo: Perspectiva, 2013.

CALVINO, Italo. Seis propostas para o próximo milênio. São Paulo: Companhia das Letras, 1990.

CAMPOS, Maria Idalina Krause de. Paul V aléry educador. Porto Alegre: Ed. Mikelis, 2018.

COMPAGNON, Antoine. A era das cartas. Belo Horizonte. Editora UFMG, 2019.

CORAZZA, Sandra Mara. Projeto de Pesquisa de Produtividade (CNPq). Didática da Tradução, transcriações do currículo: escrileituras da diferença (2014-2019).

CORAZZA, Sandra Mara. Ensaio sobre EIS AICE: proposição e estratégia para pesquisar em educação. Programa de Pós-Graduação em Educação. Porto Alegre: UFRGS, 2014. 
CORAZZA, Sandra Mara. Projeto de Pesquisa de Produtividade (CNPq). A-traduzir o arquivo da docência em aula: sonho didático e poesia curricular. (2019-2023).

DELEUZE, Gilles. Espinoza e os signos. Porto: Rés, 1970.

DELEUZE, Gilles. Diferença e repetição. Rio de Janeiro: Graal, 1988.

DELEUZE, Gilles. O abecedário de Gilles Deleuze. Vídeo. Editado no Brasil pelo Ministério da Educação: TV Escola, 2001.

DELEUZE, Gilles; GUATTARI, Félix. O que é a filosofia? Rio de Janeiro: Editora 34, 1992.

FREIRE, Paulo. Pedagogia da autonomia. São Paulo: Paz e Terra, 1996.

PASCAL, Blaise. Pensamentos. Porto Alegre: Ed. Globo, 1973.

PAZ, Otávio. Tradução: literatura e literalidade. Belo Horizonte: UFMG, 2009.

VALÉRY, Paul. L'idée fixe. Paris: Gallimard, 1932.

VALÉRY, Paul. Eupalinos on o arquiteto. São Paulo: Editora 34, 1996.

VALÉRY, Paul. Monsieur Teste. São Paulo: Ática, 1997.

VALÉRY, Paul. Meu Fausto. São Paulo: Ateliê Editorial, 2010.

VALÉRY, Paul. Variedades. São Paulo: Iluminuras, 2011.

VALÉRY, Paul. Maus pensamentos \& outros. Belo Horizonte: Âyiné, 2016.

ZOLA, Émile. La République et la littérature. Paris: G. Charpentier, 1879.

\section{Informações da autora}

Maria Idalina Krause de Campos

UFRGS

E-mail:idalinakrause@yahoo.com.br

ORCID: http://orcid.org/0000-0002-0016-7455

Link Lattes: http://lattes.cnpq.br/5668918218106014 